\author{
Wahana Sekolah Dasar \\ Tahun 26 Nomor 2 Juli 2018 \\ Hlm 51-55 \\ Tersedia Online di http://journal2.um.ac.id/index.php/wsd/ \\ ISSN 0854-8293 (cetak) ISSN 2622-5883 (online)
}

\title{
MEDIA REALIA DAN MEDIA MAYA DALAM PEMBELAJARAN AGAMA ISLAM DI SD
}

\author{
Masnunah \\ SD Bandungrejosari 3 Sukun Malang \\ masnunah62@gmail.com
}

\begin{abstract}
Abstrak: Proses penanaman konsep dan pembentukan perilaku beragama Islam dalam pembelajaran Pendidikan Agama Islam di SD dapat memanfaatkan media berbentuk media realia dan media maya. Media realia adalah semua media nyata di dalam ruang kelas dan semua media nyata yang dapat digunakan dalam kegiatan observasi pada lingkungan di luar kelas. Media maya merupakan media pembelajaran yang berbentuk digital yang diunggah dan diunduh dari dunia maya. Pemanfaatan media realia dan media maya tersebut dapat digunakan secara terpadu dalam pembelajaran PAI di sekolah dasar.
\end{abstract}

Kata Kunci: media realia, media maya, pembelajaran pendidikan agama Islam.

Media pembelajaran dapat dimanfaatkan untuk alat memudahkan penyampaian pesan dari suatu sumber pesan (guru) kepada penerima pesan (siswa). Sebagai alat bantu pembelajaran, media pembelajaran berkembang sangat pesat sesuai dengan kemajuan teknologi. Setiap jenis media memiliki karakteristik sendiri dan memiliki efektivitas masing-masing. Untuk itu, guru dapat memilih media sesuai dengan kondisi yang dihadapi

Di abad digital, Guru Pendidikan Agama Islam (PAI) dituntut terampil dalam pembelajaran agama Islam dengan mengedepankan proses penanaman konsep dan pembentukan perilaku beragama Islam dengan memanfaatkan (1) media berbentuk media realia, (2) media pembelajaran berbentuk media maya dan (3) media berbentuk media campuran (blended learning media). Untuk itu, peran media pembelajaran realia dan maya sangat penting bagi guru PAI di Sekolah Dasar.

Media berbentuk realia merupakan media ajar yang mengajarkan konsep bertitik tolak dari benda-benda secara kongkrit kepada murid. Dalam PAI, media realia cocok digunakan untuk pembentukan akidah dan akhlak dalam bentuk contoh nyata. Media maya cocok digunakan untuk pembentukan akidah dan akhlak dengan mengambil audio dan vidio yang tersedia secara online dan offline, misalnya, kisah keteladanan $25 \mathrm{Nabi}$ dan Rasul, lagu asmaul husna, dan rekaman juz 'amma. Kedua jenis media itu, yakni media realia dan media maya dapat digunakan sebagai media campuran dalam pembelajaran (blended learning).

\section{Keterampilan Literasi Murid di Abad Digital}

Abad digital membuka peluang bagi murid untuk belajar secara mandiri, dengan sokongan piranti digital dan dunia maya. Abad digital menuntut seorang murid untuk memiliki keterampilan khusus yang membantu dirinya dalam belajar secara mandiri. Murid memiliki keterampilan-keterampilan yang meski dikuasai di abad digital yakni (1) keterampilan dalam hal literasi data, (2) kemampuan dalam penguasaan teknologi, (3) kemampuan dalam melakukan kontrol diri terhadap perilaku diri sendiri. Ketiga keterampilan tersebut merupakan kemahiran yang meski dikuasai oleh seorang murid di abad digital. 
Keterampilan pertama yang meski dikuasai oleh murid di abad digital adalah kemampuan literasi data. Literasi data terdiri dari aspek (a) seleksi informasi yang dipilih, (b) seleksi informasi yang diakses, dan (c) seleksi informasi yang diserap. Keterampilan terhadap literasi data memiliki fungsi untuk membantu murid dalam melakukan pemilahan terhadap informasi abad digital.

Keterampilan kedua yang meski dikuasai oleh murid di abad digital adalah penguasaan teknologi. Penguasaan teknologi ditandai dengan (a) keterampilan dalam mengoperasikan komputer secara terbatas, (b) keterampilan dalam melakukan akses terhadap website sesuai dengan umur dan (c) keterampilan untuk menggunakan aplikasi permainan yang bertujuan untuk edukasi sesuai dengan usia. Untuk melakukan keterampilan itu, diperlukan panduan yang cukup bagi murid dari guru (Ha, dkk, 2016:547).

Keterampilan ketiga yang meski dikuasai oleh murid di abad digital adalah keterampilan melakukan kontrol diri. Keterampilan itu merupakan aktivitas yang meski dilakukan oleh seorang murid dalam hal belajar di dunia digital. Aspek-aspek yang bisa digunakan untuk kontrol diri adalah (a) kemampuan untuk manajemen waktu belajar di sekolah dengan panduan dari guru, (b) kemampuan untuk melakukan manajemen waktu rekreasi edukatif di lingkungan rumah dengan panduan guru dan orang tua dan (c) keterampilan untuk aktif di masyarakat dengan bantuan dari guru, orang tua, dan tokoh masyarakat. Dengan penguasaan keterampilan-keterampilan tersebut, seorang murid memiliki kemampuan dan keterampilan untuk self capacity building terhadap diri sendiri.

\section{Latar Literasi di Media Sosial Untuk Pembelajaran PAI}

Secara umum, ada tiga latar literasi di media sosial, yakni (1) latar jejaring sosial, (2) latar blog sosial dan (3) latar video share. Ketiga latar tersebut merupakan bagian yang tidak terpisahkan di era digital, seiring dengan perkembangan teknologi informasi dan komunikasi.

Latar jejaring sosial merupakan interaksi yang penting di media sosial. Dalam latar jejaring sosial, secara umum terbagi menjadi tiga aspek yakni (a) aspek diskusi terbuka (open discussion), (b) aspek perbincangan pribadi (private chat) dan (c) aspek surat elektronik berjejaring (mailing list). Aspek diskusi terbuka merupakan interaksi literasi yang termuat dalam sebuah web status yang diberi komentar oleh netizen. Untuk diskusi topik-topik terbaru, aspek private chat memegang peranan sebagai wadah komunikasi tertutup. Komunikasi dalam berbagi electronic file merupakan kegiatan berbagi file dalam berliterasi. Ketiga latar jejaring sosial tersebut dapat dimanfaatkan oleh guru PAI untuk mengembangkan literasi PAI dengan murid-muridnya.

Latar blog sosial merupakan latar interaksi literasi penuangan gagasan. Dalam latar blog sosial, secara umum interaksi literasi memiliki tiga aspek yakni (a) aspek berbagi data, (b) aspek berbagi tulisan pemikiran, dan (c) aspek berbagi foto. Aspek berbagi data dapat dimanfaatkan sebagai wahana untuk berbagi fakta-fakta tentang Islam yang diunggah di blog sosial. Aspek berbagi tulisan bernuansa dakwah bermakna aspek berbagi tulisan yang bisa dijadikan sarana untuk berbagi cerita, ulasan dan berbagai hal yang memiliki nuansa dakwah serta bisa dibaca oleh murid sekolah dasar. Aspek berbagi foto merupakan wahana untuk berbagi foto yang memiliki nuansa dakwah, misalnya, tempat-tempat yang menjadi lokasi perjuangan Rasulullah SAW dan para Sahabat Rasullah SAW.

Aspek video share di media sosial merupakan aspek yang tidak terpisahkan dalam latar literasi PAI. Secara umum, aspek berbagi video share dibagi menjadi tiga yakni (a) aspek unggah video, (b) aspek re-share video dan (c) aspek tanya dan jawab berbasis video editing. Aspek unggah video bermakna perekaman video dilakukan untuk merekam konten-konten bernuansa dakwah kemudian diunggah ke akun video share. Aspek re-share 
video bermakna video dakwah merupakan aspek berbagi video yang sudah diunggah melalui aspek chat di media sosial. Aspek tanya jawab berbasis video editing merupakan aspek diskusi, seorang menggunakan pertanyaan melalui video lantas oleh pihak yang lain video tersebut dijawab dengan memasang backlink (bandingkan Eglash, dkk, 2017:133).

\section{Penggunaan Media Realia Dalam PAI}

Pada umumnya, media realia telah dikenal sebagai alat bantu mengajar yang dimanfaatkan guru dalam proses pembelajaran. Media relia adalah semua media nyata di dalam ruang kelas dan semua media nyata yang dapat digunakan dalam kegiatan observasi pada lingkungan di luar kelas. Media realia dapat berupa benda atau objek yang dapat digunakan untuk membantu pembelajar, misalnya, bunga, batu, dan koran yang dibawa oleh siswa atau dibawa oleh guru. Media realia adalah alat bantu visual dalam pembelajaran yang berfungsi memberikan pengalaman langsung kepada peserta didik (Rusman, 2005). Penggunaan media realia berupa benda nyata pada proses pembelajaran PAI sangat dianjurkan agar siswa akan lebih memahami materi yang dipelajari.

Karakteristik media realia adalah benda asli, benda dalam keadaan utuh, dalam ukuran yang sebenarnya, dan dapat dikenali sebagaimana wujud aslinya. Media realia dapat berupa benda hidup (misalnya, manusia, binatang, dan tumbuhan) dan benda tidak hidup (misalnya meja, kursi, batu, makanan, dan koran). Penggunaan media sangat bergantung kepada tujuan pengajaran, bahan pengajaran, kemudahan memperoleh media yang diperlukan, dan kemampuan guru dalam menggunakannya pada kegiatan belajar mengajar di kelas (Sudjana dan Rivai, 2007).

Sebelum menggunakan media realia, tiga hal berikut perlu dipertimbangkan oleh guru. Pertama, penggunaan benda-benda atau makhluk hidup harus dipertimbangkan efisiensinya. Kedua, mengingat benda nyata memiliki banyak macamnya, mulai dari benda hidup sampai benda tidak hidup, maka penggunaan media benda hidup dan tak hidup tersebut perlu disesuiakan dengan pola pembelajaran di kelas. Ketiga, sumber, asal, dan pembiayaan perolehan benda-benda tersebut.

Lazimnya, prosedur penggunaan media realia mengikuti tahapan berikut ini. Pertama, menyediakan benda-benda nyata yang berhubungan dan relevan dengan materi pembelajaran. Kedua, menggunakan benda-benda nyata tersebut dalam proses pembelajaran di kelas dengan melibatkan siswa agar siswa mendapatkan pengalaman langsung dari benda-benda tersebut. Ketiga, melibatkan siswa mengamati secara langsung dan berdiskusi bersama temannya tentang berdasarkan hasil pengamatan media realia tersebut. Keempat, dengan bimbingan guru, siswa dapat menyimpulkan materi yang telah diajarkan.

Penggunaan media realia memilili keunggunalan, antara lain, antara lain, (1) mudah didapat, pada umumnya media realia dapat ditemui karena merupakan benda nyata yang ada di sekitar lingkungan; (2). memberikan informasi yang jelas dan akurat, mengingat benda realia merupakan benda yang nyata, maka penjelasan atau informasi yang berkaitan dengan benda tersebut menjadi jelas dan lebih akurat. Penggunaan media realia memiliki kelemahan, antara lain, (1) membawa siswa ke berbagai tempat di luar sekolah kadang mengandung resiko, misalnya, kecelakaan; (2) memerlukan biaya tidak sedikit, apalagi ditambah dengan kemungkinan kerusakan pada penggunaannya; dan (3) tidak selalu dapat memberikan semua gambaran dari objek yang sebenarnya, misalnya, pembesaran, pemotongan, dan gambar bagian demi bagian sehingga pengajaran harus didukung pula dengan media lain (Ibrahim dan Syaodih, 2003)

Berdasarkan paparan tersebut, berikut dikemukakan dua contoh penggunaan media realia dalam pembelajaran PAI di sekolah dasar.

Penanaman konsep alam mengikuti sunnatullah (hukum-hukum Allah) dapat dilakukan dengan media realia berupa pertumbuhan 
tanaman melalui praktik bertanam. Siswa diajak mengamati dan mendiskusikan munculnya tunas dari bibit yang ditanam; tumbuhnya batang, ranting, dahan, dan daun; muncul dan mekarnya bunga; dan muncul dan masaknya buah.

Penanaman konsep kemahakuasaan Allah SWT dapat dilakukan dengan kegiatan outing class, misalnya, wisata edukasi ke alam bebas untuk melihat, mengamati, dan mendiskusikan ciptaan Allah (ombak di pantai, air terjun dari sungai di bukit yang jatuh di jurang, kawah gunung dan munculnya kaldera, dan tumbuhnya pohon lebat di hutan belantara).

\section{Penggunaan Media Maya Dalam PAI}

Media maya merupakan media pembelajaran yang berbentuk digitalyang diunggah dan diunduh dari dunia maya. Saat ini, media maya sedang gencar dikembangkan sebagai bagian dari kelas maya (virtual class). Dalam situs web http://www.yuksinau.id disebutkan tentang tujuan, manfaat, fitur, dan keunggulan dan kelebihan kelas maya. Berdasarkan paparan tentang kelas maya tersebut, berikut dikemukakan dua karekteristik media maya berikut ini.

Pertama, media maya dapat (1) digunakan kapan saja dan dimana saja dengan menghemat waktu dan biaya; (2) dimanfaatkan untuk meningkatkan keterampilan penggunaan teknologi IT; (3) digunakan untuk meningkatkan kreativitas siwa; dan (4) diberdayakan untuk lebih memaksimalkan kemampuan pribadi masing-masing siswa, baik di luar kelas maupun di kelas tatap muka. Kedua, media maya dapat memberi manfaat (1) meningkatkan keluasan dan keragaman materi pembelajaran, (2) meningkatkan kesesuaian materi dengan kebutuhan siswa, (3) meningkatkan efisiensi waktu belajar; (4) mengurangi ketergantungan pada buku teks sehingga bisa menghemat penggunaan kertas; (5) menjalin konektivitas dan kemudahan memperoleh informasi yang aktual; (6) memiliki fleksibitas belajar di mana saja dan kapan saja; (7) meningkat- kan interaksi dan kolaborasi, dan (8) memiliki kemutakhiran informasi karena ketersediaan konten digital.

Berdasarkan paparan tersebut, berikut dikemukakan dua contoh penggunaan media maya dalam pembelajaran PAI di sekolah dasar

Pembelajaran hafalan 99 nama Allah (asmaul husna) dan maknanya dapat dilakukan dengan mudah dengan memanfaatkan audiovideo anak-anak Runa dan Sakira dalam https:// www.youtube.com/watch? $\mathrm{v}=\mathrm{maV0z0HT91E}$

Penanaman konsep rukun dan tatacara salat fardlu dapat dilakukan dengan video Ayo Belajar Sholat https://www.youtube.com/ watch? $\mathrm{v}=\mathrm{K} 11 \mathrm{~S} 2-3 \mathrm{zYg} 4$.

Media maya tersebut dapat difungsikan sebagai penambahan dan pengayaan pembelajaran dan pengganti sebagian pembelajaran. Media maya tersebut mempunyai fiturfitur yang menarik dan memudahkan guru dalam proses pembelajaran, antara lain, (1) mudah mencari konten yang relevan dengan tujuan belajar; (2) dapat membantu siswa belajar melalu contoh dan praktik; dan (3) dapat memberikan variasi pembelajaran baik secara langsung dengan instruktur (synchronous) maupun secara individu atau otodidak (asynchronous).

Dewasa ini, media maya memiliki sejumlah kelebihan, antara lain, (1) proses pembelajaran lebih menarik karena bersifat interaktif; (2) pembelajaran fleksibel karena pembelajaran tidak terikat tempat dan waktu secara ketat sehingga lebih santai; (3) proses belajar memfasilitasi siswa lebih aktif dalam mempelajari materi yang disampaikan oleh guru melalui website. Di samping kelebihannya, media maya memiliki sejumlah kekurangan, antara lain, (1) memerlukan fasilititas koneksi internet, komputer, proyektor, dan peralatan pendukung tampilan lainnya; (2) memerlukan pengawasan dan pemilihan yang cermat atas konten audio vidEo agar terhindar dari konten negatif; dan (3) memerlukan pengelolaan yang hati-hati saat akses media internet se- 
cara langsung untuk menghindari siswa lebih asik bermain internet dibandingkan belajar materi yang disampaikan.

\section{SIMPULAN}

Dewasa ini, dunia nyata dan dunia maya berdampingan sebagai sumber informasi dan memiliki kedudukan yang imbang dalam proses literasi anak. Dunia nyata dapat digunakan sebagai media realia dalam pembelajaran agama Islam dalam konteks "bacaan" siswa terhadap makhluk ciptaan Allah. Dunia maya dapat digunakan sebagai media maya dalam pembelajaran agama Islam dalam konteks sediaan informasi yang melimpat, baik berupa informasi tulis, audio, maupun video.

Dengan demikian, proses penanaman konsep dan pembentukan perilaku beragama Islam dalam pembelajaran Pendidikan Agama Islam di SD dapat memanfaatan media berbentuk media realia dan media maya. Media relia adalah semua media nyata di dalam ruang kelas dan semua media nyata yang dapat digunakan dalam kegiatan observasi pada lingkungan di luar kelas. Media maya merupakan media pembelajaran yang berbentuk digital yang diunggah dan diunduh dari dunia maya. Pemanfaatan media realia dan media maya tersebut dapat digunakan secara terpadu dalam pembelajaran PAI di sekolah dasar.

\section{DAFTAR RUJUKAN}

Chen, B. 2015. Exploring the Digital Divide: The Use of Digital Technologies in Ontario Public Schools. Canadian Journal of Learning and Technology/La revue canadienne de l'apprentissage et de la technologie, 41(3).

Eglash, R., Babbitt, W., Bennett, A., Bennett, K., Callahan, B., Davis, J., ... \& Lachney, M. 2017. Culturally Situated Design Tools: Generative Justice as a Foundation for STEM Diversity. In Moving Students of Color from Consumers to Producers of Technology (pp. 132-151). IGI Global.

Ha, V. S., \& Whittaker, A. 2016. 'Closer to my world': Children with autism spectrum disorder tell their stories through photovoice. Global public health, 11(5-6), 546-563. http://www.yuksinau.id/kelasmaya/. 2018. "Kelas Maya (Lengkap): Jenis, Tujuan, Manfaat, Contoh"

Ibrahim, \& Syaodih, N. 2003. Perencanaan Pengajaran. Jakarta: Rineka Cipta.

James, C., Gruner, D. T., Lee, A., \& Mullen, M. 2016. Getting Into the Fray: Civic Youth, Online Dialogue, and Implications for Digital Literacy Education. Journal of Digital and Media Literacy, 4.

Rusman. 2005. Model-Model Pembelajaran Mengembangkan Profesionalisme Guru. Jakarta: PT Raja Grafindo Persada.

Sudjana, N., \& Rivai, A. (2007). Media Pengajaran. Bandung: Sinar Baru Algesindo. 